\title{
Response of Guava cv. L-49 to Urea and Murate of potash fertigation levels
}

\author{
DK Sarolia, KD Ameta, SK Sharma \& RK Meena
}

Journal of Agriculture and Ecology

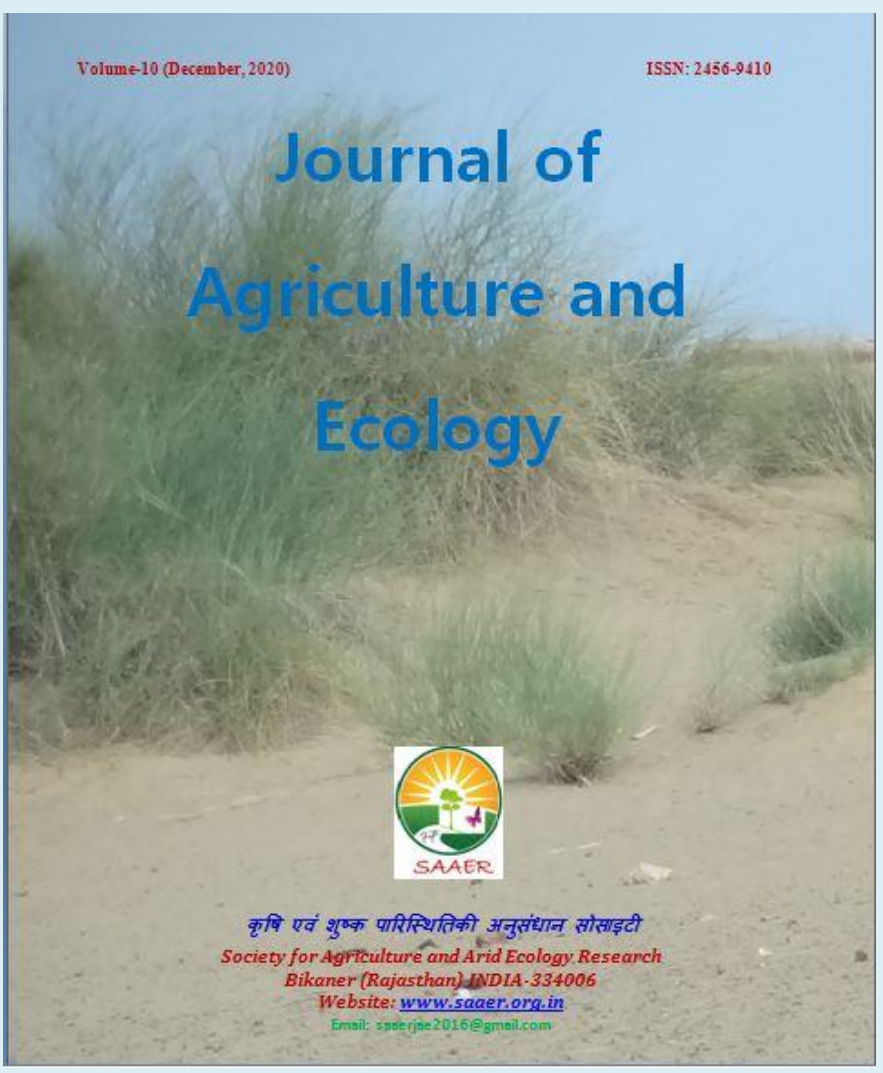

ISSN: 2456-9410

Volume: 10

Journal of Agriculture and Ecology (2020) 10: 76-82 http://doi.org/10.53911/JAE.2020.10207

कृषि एवं शुष्क पारिस्थितिकी अनुसंधान सोसाइटी Bikaner (Rajas Email: 


\title{
Response of Guava cv. L-49 to Urea and murate of potash fertigation levels
}

\author{
DK Sarolia ${ }^{1} \rrbracket$, KD Ameta ${ }^{2}$, SK Sharma ${ }^{3} \&$ RK Meena ${ }^{4}$ \\ ${ }^{1 \& 4}$ Sr. Scientist (Fruit Science), ICAR-CIAH, Bikaner (Rajasthan) \\ ${ }^{2}$ Asstt. Professor, Department of Horticulture, RCA, Udaipur (Rajasthan) \\ ${ }^{3}$ Professor \& Director Research, MPUAT, Udaipur (Rajasthan) \\ $\forall$ Corresponding author: DK Sarolia,E-mail: deephorti@gmail.com
}

\section{Article Info}

Article history

Received: 25 October 2020

Accepted: 15 December 2020

Available online: 31 December 2020

Key Words: Fertilizer use efficiency, guava, low cost fertigation, traditional fertilizers (urea \& MOP).

\begin{abstract}
Farmer's practices of guava cultivation in trend with basin irrigation and basal fertilizer application, which has low application and use efficiencies. However, some farmers in the state are reluctant to adopt drip technology, due to lack of information on fertigation scheduling and high cost of water soluble fertilizers (WSF) this practice not in vogue. Now need to assess basal fertilizer doses application through drip for better use efficiency. Guava cv. L-49 imposed to apply eleven treatment combinations comprised viz., Farmer's practice (basin \& basal application) with urea and murate of potash fertigation levels viz., Farmer's practices (basin \&basal application) $\left(\mathrm{T}_{1}\right)$, drip irrigation and basal application of fertilizers $\left(\mathrm{T}_{2}\right), 50 \% \mathrm{RDF}$ $(\mathrm{N}+\mathrm{K})$ at 3 days interval through fertigation $\left(\mathrm{T}_{3}\right), 50 \% \mathrm{RDF}(\mathrm{N}+\mathrm{K})$ at 5 days interval through fertigation $\left(\mathrm{T}_{4}\right), 50 \% \mathrm{RDF}(\mathrm{N}+\mathrm{K})$ at 7 days interval through fertigation $\left(\mathrm{T}_{5}\right), 75 \% \mathrm{RDF}(\mathrm{N}+\mathrm{K})$ at 3 days interval through fertigation $\left(\mathrm{T}_{6}\right), 75 \% \operatorname{RDF}(\mathrm{N}+\mathrm{K})$ at 5 days interval through fertigation $\left(\mathrm{T}_{7}\right)$, $75 \% \mathrm{RDF}(\mathrm{N}+\mathrm{K})$ at 7 days interval through fertigation $\left(\mathrm{T}_{8}\right), 100 \% \mathrm{RDF}$ $(\mathrm{N}+\mathrm{K})$ at 3 days interval through fertigation $\left(\mathrm{T}_{9}\right), 100 \% \mathrm{RDF}(\mathrm{N}+\mathrm{K})$ at 5 days interval through fertigation $\left(\mathrm{T}_{10}\right)$ and $100 \% \mathrm{RDF}(\mathrm{N}+\mathrm{K})$ at 7 days interval through fertigation $\left(\mathrm{T}_{11}\right)$. All observations were recorded from winter season crop. Treatment $\mathrm{T}_{11}(100 \% \mathrm{RDF}(\mathrm{N}+\mathrm{K})$ at 7 days interval through fertigation) additional produced fruit yield of $8.12 \mathrm{q} \mathrm{ha}^{-1}$ in comparison to the farmer's practices $\left(\mathrm{T}_{1}\right)$.
\end{abstract}

Copyright (C) Sarolia et al., This is an open access article published under the terms of the Creative Commons Attribution License, which permits unrestricted use, distribution, and reproduction in any medium, provided the original work is properly cited.

Preferred citation: Sarolia DK, Ameta KD, Sharma SK \& Meena RK. 2020. Response of Guava cv. L-49 to Urea and murate of potash fertigation levels. Journal of Agriculture and Ecology, 10: 76-82; http://doi.org/10.53911/JAE.2020.10207.

\section{Introduction}

Guava (Psidium guajava L.) is an important fruit crop grown in almost all parts of India and is one of the preferred fruit crops in Southern Rajasthan. Commercial varieties in this area are L-49, Allahabad Safeda and
Burfkhan genotype. Farmer's practices of guava cultivation in trend with basin irrigation and basal fertilizer application, which has low application and use efficiencies. However, some farmers in the state are reluctant to adopt drip technology, 
due to lack of information on fertigation scheduling and high cost of water soluble fertilizers (WSF). Earlier experiments results have clearly revealed that through fertigation in guava could be saved about 40-50 per cent nutrients (Ramniwas et al. 2013; Sarolia et al. 2015). One of the reasons might be limited adoption of fertigation despite savings of fertilizer is attributed to non availability of water-soluble fertilizer at affordable cost. Hence, the present study was undertaken to work out the suitable doses of water soluble common fertilizers (urea \& MOP) on the basis of fertigation experiment. It is fact that drip irrigation improves the water and fertilizer use efficiency besides improving the yield and quality of produce (Singh et al. 2003; Shukla et al. 2017). Keeping in view the present experiment was conducted

\section{Materials and Methods}

A field experiment on guava cv. L-49 was conducted at Horticulture Farm, Rajasthan College of Agriculture, Maharana Pratap University of Agriculture and Technology, Udaipur, Rajasthan during the year 2012-15. Experimental orchard was situated at $24^{\circ} 34^{\prime} \mathrm{N}$ latitude and $73^{\circ} 42^{\prime} \mathrm{E}$ longitude at an elevation of 582.17 meters above mean sea level. The soil of the experimental field was clay loamy in texture, slightly alkaline in reaction $(8.5 \mathrm{pH})$, low in available nitrogen $\left(253.5 \mathrm{~kg} \mathrm{ha}^{-1}\right)$, medium in organic-carbon $(0.75 \%)$, available phosphorus (27.5) and available potassium (271.4 $\left.\mathrm{kg} \mathrm{ha}^{-1}\right)$. Selected three year old guava cv. L-49 plants for study planted at $5 \times 5$ metre spacing and treatments were allocated under randomized block design fashion with thrice replications. Constantly applied drip irrigation at $0.75 \mathrm{CPE}$ at alternate day on cumulative pan evaporation basis.

Eleven treatment combinations comprised with viz., Farmer's practice (basin $\&$ basal application) $\left(\mathrm{T}_{1}\right)$, drip irrigation and Basal application of fertilizers $\left(\mathrm{T}_{2}\right), 50 \% \mathrm{RDF}$ $(\mathrm{N}+\mathrm{K})$ at 3 days interval through fertigation $\left(\mathrm{T}_{3}\right), 50 \% \mathrm{RDF}(\mathrm{N}+\mathrm{K})$ at 5 days interval through fertigation $\left(\mathrm{T}_{4}\right), 50 \% \mathrm{RDF}$ $(\mathrm{N}+\mathrm{K})$ at 7 days interval through fertigation $\left(\mathrm{T}_{5}\right), 75 \% \mathrm{RDF}(\mathrm{N}+\mathrm{K})$ at 3 days interval through fertigation $\left(\mathrm{T}_{6}\right), 75 \% \mathrm{RDF}$ $(\mathrm{N}+\mathrm{K})$ at 5 days interval through fertigation $\left(\mathrm{T}_{7}\right), 75 \% \mathrm{RDF}(\mathrm{N}+\mathrm{K})$ at 7 days interval through fertigation $\left(\mathrm{T}_{8}\right), 100 \% \mathrm{RDF}$ $(\mathrm{N}+\mathrm{K})$ at 3 days interval through fertigation $\left(\mathrm{T}_{9}\right), 100 \% \mathrm{RDF}(\mathrm{N}+\mathrm{K})$ at 5 days interval through fertigation $\left(\mathrm{T}_{10}\right)$ and $100 \% \mathrm{RDF}$ $(\mathrm{N}+\mathrm{K})$ at 7 days interval through fertigation $\left(\mathrm{T}_{11}\right)$.

Calculated dose of fertilizers and method of application

\begin{tabular}{lllll}
\hline \multirow{2}{*}{ Fertilizers } & \multicolumn{3}{l}{ Amount of fertilizers g/plant/year } & Application \\
\cline { 2 - 5 } & $\mathbf{5 0 \%}$ & $\mathbf{7 5 \%}$ & $\mathbf{1 0 0 \%}$ & method \\
\hline Urea & 165 & 245 & 330 & Splits through drip \\
SSP & 187.5 & 280 & 375 & Basal \\
MOP & 125 & 187.5 & 250 & Splits through drip \\
\hline
\end{tabular}

* Fertilizer dose NPK plant ${ }^{-1}$ @ 50: $2050 \mathrm{~g} \mathrm{year}^{-1}$ and 150:60:150 g for three year old plant.

Time and methods of treatment recommended dose of single super phosphate, application: Basal application of FYM (10 kg plant ${ }^{-1}$ year $\left.{ }^{-1}\right)$ were applied on 
July first week. Fertigation in ten equal split doses (after fruit set stage) were supplied.

Fig 1. Meteorological observations during experimentation

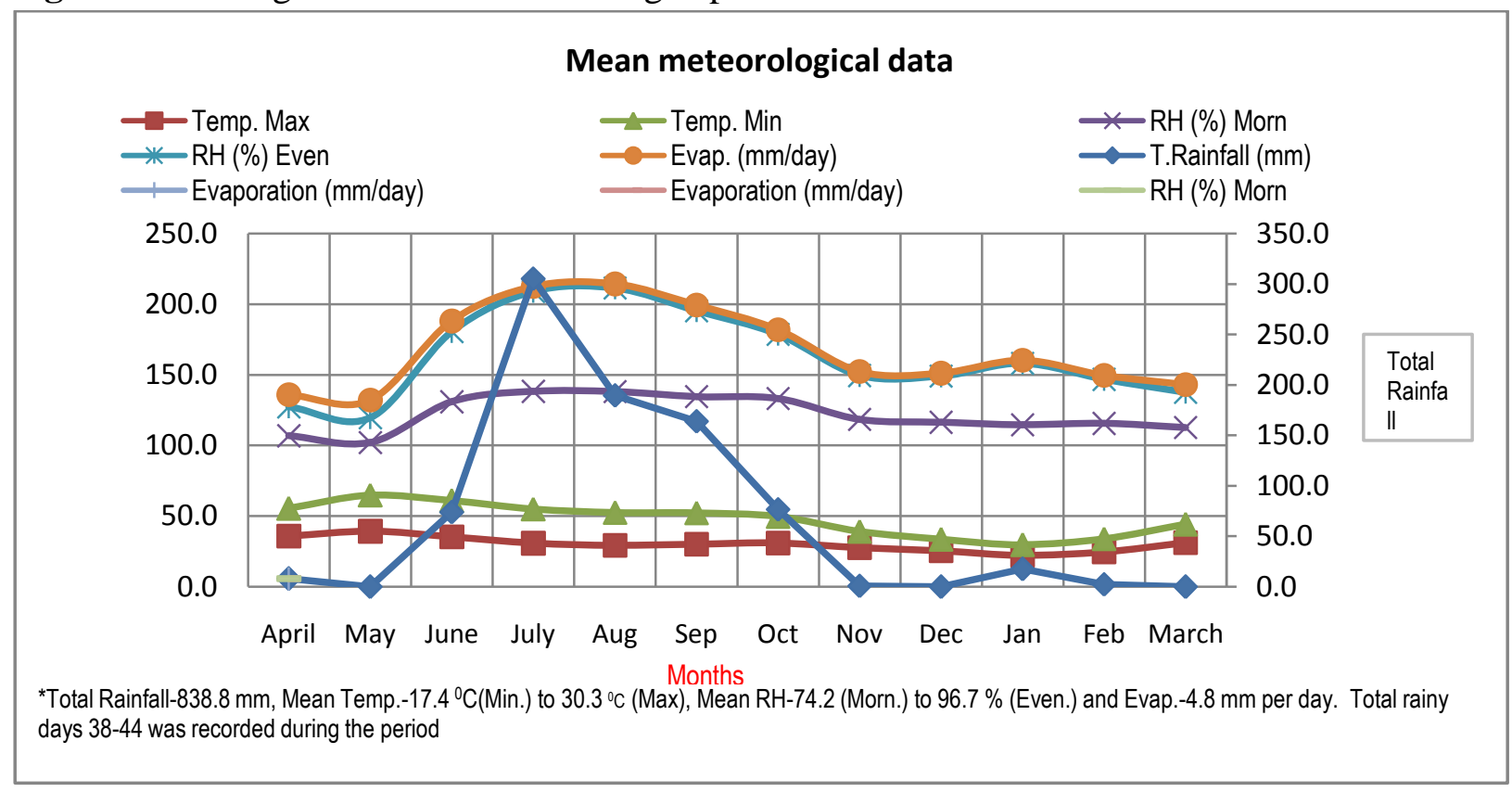

Observations recorded: Growth parameters viz., plant height, spread (EW \& NS), canopy height measured by tape and girth by use of verneer caliper with these recorded data calculated canopy volume $\left(\mathrm{m}^{3}\right)$ by formula $=$ $r^{3} x\left(2 / 3 X+X^{3} / 3\right)$ whereas $r=$ canopy radius and $\mathrm{x}=$ canopy height (Singh et al. 2003). Fruit number was counted, weight with help of balance and size with verneer caliper was recorded at fruit maturity stage. Mature fruits were harvested periodically from each treatment separately and the weight was recorded with the help of single pan balance and expressed in $\mathrm{kg}$. Further, for each harvest were recorded and fruits/ha were calculated by multiplying the fruit yield/plant to the number of plants/ ha (400). Quality test were carried out on 10 fruits from all the directions of a plant for TSS $\left({ }^{\circ} \mathrm{B}\right)$ with the help of hand refractometer, acidity by $0.1 \mathrm{~N} \mathrm{NaOH}$ and ascorbic acid by DCIP dye titration method (AOAC 1995) as well as seed index on count of 100 seeds and also counted total seeds per fruit as per standard methods. Available NPK status of soil (Jackson 1967) and $\mathrm{pH}$ determine (Linder 1944). The data obtained on various characters were subjected to Factorial Randomized Block Design analysis and interpretation of the data was carried out in accordance to Panse \& Sukhatme (1985).

\section{Results and Discussion}

This trial were initiated on three year old uniform plants and applied treatments as per programme, in this plot fruiting were observed. The initial results indicated that irrigation at $0.75 \mathrm{CPE}$ with $100 \% \mathrm{RDF}$ recorded higher vegetative and yield attributes. Growth of the plant with regards to plant height, spread, stem diameter, canopy height and canopy volume recorded and 
observed no any specific trends with applied treatments. However, canopy volume of the treatments $T_{1}$ to $T_{3}$ have same value i.e., 0.10 m3 might be due to initial years main axis growth of the plant. Maximum plant height
(2.54 m), spread (2.45 m EW x $2.18 \mathrm{~m} \mathrm{NS}$ ), stem girth $(5.81 \mathrm{~cm})$, canopy volume $(0.29$ $\left.\mathrm{m}^{3}\right)$ were recorded in treatment $\mathrm{T}_{11}(100 \%$ $\mathrm{RDF}(\mathrm{N}+\mathrm{K})$ at 7 days interval through fertigation).

Table 1. Vegetative growth of guava cv. L-49 under drip irrigation

\begin{tabular}{ccccccc}
\hline Treatments & $\begin{array}{c}\text { Plant height } \\
(\mathbf{m})\end{array}$ & $\begin{array}{c}\text { Stem girth } \\
(\mathbf{c m})\end{array}$ & \multicolumn{2}{c}{$\begin{array}{c}\text { Plant spread } \\
(\mathbf{m})\end{array}$} & $\begin{array}{c}\text { Canopy } \\
\text { height } \\
(\mathbf{m})\end{array}$ & $\begin{array}{c}\text { Canopy } \\
\text { volume } \\
\left(\mathbf{m}^{\mathbf{3}}\right)\end{array}$ \\
\hline $\mathrm{T}_{1}$ & 1.58 & 4.50 & 1.50 & 1.50 & 0.56 & 0.10 \\
$\mathrm{~T}_{2}$ & 1.55 & 3.21 & 1.10 & 1.15 & 0.60 & 0.10 \\
$\mathrm{~T}_{3}$ & 1.63 & 3.72 & 1.70 & 1.23 & 0.51 & 0.10 \\
$\mathrm{~T}_{4}$ & 1.73 & 4.26 & 1.78 & 1.88 & 0.50 & 0.16 \\
$\mathrm{~T}_{5}$ & 1.70 & 3.55 & 1.70 & 1.77 & 0.49 & 0.11 \\
$\mathrm{~T}_{6}$ & 2.01 & 3.10 & 1.80 & 1.80 & 0.48 & 0.15 \\
$\mathrm{~T}_{7}$ & 2.16 & 3.12 & 1.79 & 1.91 & 0.50 & 0.17 \\
$\mathrm{~T}_{8}$ & 2.13 & 3.09 & 1.95 & 1.80 & 0.45 & 0.20 \\
$\mathrm{~T}_{9}$ & 2.26 & 5.12 & 2.35 & 1.84 & 0.44 & 0.29 \\
$\mathrm{~T}_{10}$ & 2.30 & 3.80 & 2.15 & 2.03 & 0.49 & 0.25 \\
$\mathrm{~T}_{11}$ & 2.54 & 5.81 & 2.45 & 2.18 & 0.46 & 0.29 \\
\hline $\mathrm{SEm} \pm$ & 0.29 & 0.20 & 0.32 & 0.26 & 0.06 & 0.05 \\
$\mathrm{CD}$ at $5 \%$ & 0.87 & 0.60 & 0.96 & 0.78 & NS & 0.15 \\
\hline
\end{tabular}

Table 2. Yield parameters of guava cv. L-49 under drip irrigation

\begin{tabular}{|c|c|c|c|c|c|c|}
\hline \multirow[t]{2}{*}{ Treatments } & \multirow{2}{*}{$\begin{array}{l}\text { No. of } \\
\text { fruits per } \\
\text { plant }\end{array}$} & \multirow{2}{*}{$\begin{array}{l}\text { Fruit } \\
\text { weight } \\
\text { (g) }\end{array}$} & \multicolumn{2}{|c|}{ Fruit size (cm) } & \multirow{2}{*}{$\begin{array}{c}\text { Yield plant } \\
1 \\
(\mathrm{~kg})\end{array}$} & \multirow{2}{*}{$\begin{array}{l}\text { Estimated } \\
\text { yield ha-1 } \\
\text { (q) }\end{array}$} \\
\hline & & & Length & Breadth & & \\
\hline $\mathrm{T}_{1}$ & 25 & 210.0 & 5.14 & 4.25 & 5.25 & 21.00 \\
\hline $\mathrm{T}_{2}$ & 31 & 219.3 & 5.13 & 4.90 & 6.80 & 27.20 \\
\hline $\mathrm{T}_{3}$ & 25 & 190.0 & 4.98 & 4.24 & 4.75 & 19.00 \\
\hline $\mathrm{T}_{4}$ & 27 & 167.8 & 4.52 & 4.32 & 4.53 & 18.12 \\
\hline $\mathrm{T}_{5}$ & 26 & 170.0 & 4.59 & 4.30 & 4.42 & 17.68 \\
\hline $\mathrm{T}_{6}$ & 27 & 177.0 & 4.58 & 4.26 & 4.77 & 19.08 \\
\hline $\mathrm{T}_{7}$ & 26 & 160.7 & 4.45 & 4.26 & 4.18 & 16.72 \\
\hline $\mathrm{T}_{8}$ & 30 & 195.5 & 4.84 & 4.63 & 5.86 & 23.44 \\
\hline $\mathrm{T}_{9}$ & 33 & 214.4 & 4.96 & 4.75 & 7.06 & 28.24 \\
\hline $\mathrm{T}_{10}$ & 30 & 216.6 & 4.92 & 4.80 & 6.50 & 26.00 \\
\hline $\mathrm{T}_{11}$ & 33 & 220.8 & 5.30 & 4.95 & 7.28 & 29.12 \\
\hline $\mathrm{SEm}+$ & 1.87 & 9.12 & 0.26 & 0.24 & 0.58 & 2.32 \\
\hline $\mathrm{CD}$ at $\overline{5 \%}$ & 5.61 & 27.36 & 0.72 & NS & 1.74 & 6.96 \\
\hline
\end{tabular}

First harvest obtained with the range of different fruiting and yield parameters as number of fruits 25-33, fruit weight 190-220.8

$\mathrm{g}$ and yield per plant $4.18-7.78 \mathrm{~kg}$. Treatment $\mathrm{T}_{11}$ showing better effect and more yield attributes i.e., fruit weight (220.8 g), number, 
diameter $(5.30 \mathrm{~cm}$ polar $\mathrm{x} 4.95 \mathrm{~cm}$ Equatorial) and yield $(7.28 \mathrm{~kg} / \mathrm{plant})$. These results are with the cognitions of the findings of Sarolia et al. (2014\& 2015) in guava. Quality (TSS, acidity content, seed index seed hardness and shelf life) attributes wise not much variation were observed with the fertigation treatments. Treatment level $T_{1}$ to $T_{5}$ has same and higher value of TSS over rest of the treatments. Similar trend were observed in acidity $(0.30 \%)$, Seed content per fruits range value 138-154 and ascorbic acid 172 to $182.1 \mathrm{mg}$ per 100g. $\mathrm{T}_{8}(75 \%$ RDF) level recorded higher fruit quality in terms of TSS $\left(12.4{ }^{0} \mathrm{~B}\right)$, vitamin C (182.1 mg/100g) and shelf life (4.2 days). This probably might be due to sometime higher dose of fertilizers only can be enhanced physical parameters (weight and grade) of fruit need not the bio-chemical attributes. The results also found analogous with this findings of Firake \& Kumbhar (2002), Ramniwas et al. (2012) and Lahoty et al. (2016).

Table 3. Fruit quality parameters of guava cv. L- 49 under drip irrigation

\begin{tabular}{ccccccc}
\hline Treatments & $\begin{array}{c}\text { TSS } \\
\left({ }^{\mathbf{O}} \mathbf{B}\right)\end{array}$ & $\begin{array}{c}\text { Acidity } \\
(\boldsymbol{\%})\end{array}$ & $\begin{array}{c}\text { No. of } \\
\text { seeds/fruit }\end{array}$ & $\begin{array}{c}\text { 100 seed } \\
\text { weight }(\mathbf{g})\end{array}$ & $\begin{array}{c}\text { Ascorbic } \\
\text { acid } \\
(\mathbf{m g} / \mathbf{1 0 0})\end{array}$ & $\begin{array}{c}\text { Shelf life } \\
\text { (Days) }\end{array}$ \\
\hline $\mathrm{T}_{1}$ & 12.4 & 0.32 & 154 & 1.50 & 175.5 & 4.1 \\
$\mathrm{~T}_{2}$ & 12.4 & 0.32 & 146 & 1.46 & 179.3 & 4.1 \\
$\mathrm{~T}_{3}$ & 12.4 & 0.31 & 142 & 1.44 & 182.1 & 4.2 \\
$\mathrm{~T}_{4}$ & 12.4 & 0.32 & 147 & 1.48 & 179.5 & 4.1 \\
$\mathrm{~T}_{5}$ & 12.4 & 0.31 & 140 & 1.45 & 180.4 & 4.2 \\
$\mathrm{~T}_{6}$ & 12.2 & 0.33 & 138 & 1.42 & 180.7 & 4.0 \\
$\mathrm{~T}_{7}$ & 12.2 & 0.33 & 155 & 1.50 & 173.7 & 4.0 \\
$\mathrm{~T}_{8}$ & 12.2 & 0.31 & 154 & 1.60 & 172.5 & 4.5 \\
$\mathrm{~T}_{9}$ & 12.2 & 0.32 & 148 & 1.55 & 175.5 & 4.6 \\
$\mathrm{~T}_{10}$ & 12.0 & 0.31 & 144 & 1.53 & 177.6 & 4.2 \\
$\mathrm{~T}_{11}$ & 12.0 & 0.31 & 145 & 1.52 & 180.7 & 4.4 \\
\hline $\mathrm{SEm} \pm$ & 0.15 & 0.04 & 2.80 & 0.20 & 3.13 & 0.20 \\
$\mathrm{CD}$ at $5 \%$ & $\mathrm{NS}$ & $\mathrm{NS}$ & 8.40 & $\mathrm{NS}$ & 9.39 & $\mathrm{NS}$ \\
\hline
\end{tabular}

Table 4. Soil nutrient status

Soil parameters

Available NPK (kg/ha.) and pH status in soil $30 \mathrm{~cm} \quad 60 \mathrm{~cm} \quad 90 \mathrm{~cm}$

\begin{tabular}{ccccccc} 
& April & Nov. & April & Nov. & April & Nov. \\
\hline Available N & 330.63 & 374.52 & 283.42 & 320.71 & 255.65 & 280.64 \\
Available P & 19.34 & 21.16 & 17.55 & 19.23 & 13.80 & 15.42 \\
Available K & 361.22 & 392.71 & 310.60 & 348.71 & 275.65 & 288.90 \\
pH & 8.0 & 8.0 & 8.1 & 8.3 & 8.4 & 8.5 \\
\hline
\end{tabular}


Available NPK and $\mathrm{pH}$ status with depth of the soil i.e., 30, 60 and $90 \mathrm{~cm}$ during April and Nov. months. Reduced NPK status with increasing the depth and November month these nutrient content status higher over April month in all the depths. While, $\mathrm{pH}$ value enhanced with the depth and marginal increment was recorded in Nov., over April month. The present results are in partial agreement with the findings of Ramniwas et al. (2013). Thus, plant received treatment 100 $\% \operatorname{RDF}(\mathrm{N}+\mathrm{K})$ at 7 days interval through fertigation resulted in better vegetative growth, higher fruit yield and satisfactory fruit quality attributes. This level was yielded additional $8.12 \mathrm{q} \mathrm{ha}^{-1}$ fruits in comparison to the farmer's practices $\left(\mathrm{T}_{1}\right)$ at first fruiting.

\section{Acknowledgement}

Authors thankful to Department of Horticulture, Rajasthan College of Agriculture, Government of Rajasthan and Directorate of Research, MPUAT, Udaipur for providing fund and facilities for completion of the project (Need based project-drip fertigation).

\section{References}

AOAC. 1995. Official Method of Analysis of Association of Official Analytical Chemist. Washington, D. C. pp: 16: 37.

Firake NN \& Kumbhar DB. 2002. Effect of different levels of $\mathrm{N}, \mathrm{P}$ and $\mathrm{K}$ fertigation on yield and quality of pomegranate. Journal of Maharashtra Agriculture University, 27:146-148.

Jackson WL. 1967. Soil Chemical Analysis, Prentice Hall of India Pvt. Ltd., New Delhi, pp: 183-192.
Lahoty Pravisha, Kaushik RA \& Sarolia DK. 2016. Effect of low cost fertigation levels on flowering characters, yield and nutrient uptake of guava (Psidium guajava L.) under ultra high density planting system. International Journal of Bio-resource and Stress Management, 7 (6spl.):179182.

Linder RC. 1944. Rapid analytical methods for some of the more common substances of plant and soil. Plant Physiology, 19: 76-84.

Panse VG \& Sukhatme PV.1985. Statistical methods for Agriculture workers. ICAR, New Delhi, pp: 145-155.

Ramniwas, Kaushik RA, Pareek S, Sarolia DK \& Virendra S. 2013. Effect of Drip Fertigation Scheduling on Fertilizer Use Efficiency, Leaf Nutrient Status, Yield and Quality of 'Shweta' Guava (Psidium guajava L.) Under Meadow Orcharding. Natl. Acad. Sci. Lett., 36(5):483-488.

Ramniwas, Kaushik RA \&.Sarolia DK. 2012. Response of irrigation and fertigation scheduling on flowering, physiological parameters and fruit yield of guava (Psidium guajava L.) under high density planting. Annals of Agriculture Research New Series, 33 (3): 1-6.

Sarolia DK, Singh V \& Kaushik R A.2015. Mango and Guava production technology (Hindi), AICRP on fruits, Department of Horticulture, RCA, MPUAT, Udaipur, pp: 1-34.

Sarolia DK, Ameta KD \& Sharma SK. 2014. Response of guava cv. L-49 to 
fertigation through urea and MOP under Southern Rajasthan conditions. Project report "Need based project on drip", Govt. of Rajasthan, pp:1-14.

Shukla AK, Sarolia DK, Kaushik RA \& Singh V. 2017. Effect of micro irrigation on growth, yield and quality of L-49 guava under semi arid conditions of Rajasthan. Journal of Agriculture and Ecology, 3: 33-37.
Singh G, Rajan S \& Singh AK. 2003. Approaches and strategies for precision farming in guava. In: Precision Farming in Horticulture. (Eds) Singh H. P., Singh G, Samual J. C. and Pathak R. K. NCPAH, DAC, MoA, PFDC, CISH, pp: 92-113.

Singh G, Mishra AK, Hareeb M, Tandon DK and Pathak RK. 2003. The Guava Extension Bulletin17, CISH, Lucknow, pp: 1-30. 